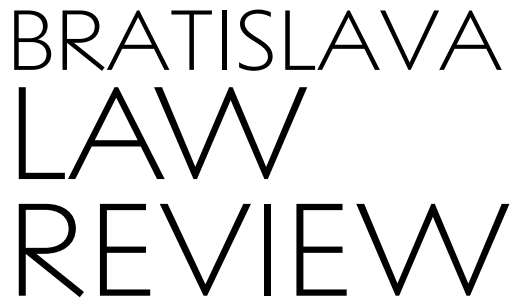

PUBLISHED BY

THE FACULTY OF LAW, COMENIUS UNIVERSITY IN BRATISLAVA

\title{
SCANDINAVIAN LEGAL REALISM AND THE CHALLENGE OF RECOGNIZING EMERGENCY MEDICAL SERVICE AS A LEGAL NORM / Jenna Uusitalo
}

\author{
Jenna Uusitalo, M.A. in Law; \\ PhD. student, Faculty of Law, \\ University of Helsinki, P.O. Box 4, \\ 00014 University of Helsinki, Finland; \\ jenna.uusitalo@helsinki.fi; \\ ORCID: 0000-0002-7799-7289.
}

\begin{abstract}
Emergency medical service (EMS) forms a sub-category of the internationally recognized right to health. However, despite the codification of the right to health in various human rights conventions which have been implemented in national legislation, EMS still seems to be regarded as an economic expense or a political decision rather than a legal norm or a human right. This paper evaluates the causes for such a misunderstanding, primarily through Scandinavian Legal Realism which emphasizes the social contextualization of law. Supplementary scholarly views, as well as a history of human rights, are also applied to support the main arguments. Essentially, the paper claims that the challenge of recognizing EMS as a legal norm is associated with the relatively abstract and impersonalized nature of emergency care.
\end{abstract}

Key words: Emergency Medical Service; Human Rights; Legal Philosophy; Scandinavian Legal Realism

\section{Suggested citation:}

Uusitalo, J. (2020). Scandinavian Legal Realism and the Challenge of Recognizing Emergency Medical Service as a Legal Norm. Bratislava Law Review, 4(2), 129-146.

https://doi.org/10.46282/blr.2020.4.2.192
Accepted: 07 September 2020

Published: 31 December 2020

\section{INTRODUCTION}

In 2015, the Parliamentary Ombudsman of Finland published a decision according to which equal access to emergency medical care in Finland was compromised because of dead zones within the emergency medical service helicopters' (HEMS) geographical area of operation. ${ }^{1}$ Despite the explicit constitutional references in the decision, the Ministry of Social Affairs and Health, as a responsible authority on the matter, was of the opinion that the issue was solely a political one and could not be resolved without due consideration of the budget (Mansikka, 2018; Ministry of Social Affairs and Health, 2018). Therefore, the new HEMS bases cannot be established until 2022 at the earliest, i.e., seven years after the Parliamentary Ombudsman's observations.

Contrary to the Ministry's perception, emergency medical service (EMS) is not merely a political or economic decision, but a legal norm which has a strong basis in international human rights law. While no international or regional human rights document refers to EMS specifically, it forms a de jure sub-category of the right to health, which

1 The Decision of the Parliamentary Ombudsman of Finland (2015). En Jämlik Tillgänglighet av Läkarhelikoptrar. Dnro 1989/4/14. 
itself has been recognized by international human rights law. ${ }^{2} \mathrm{An}$ additional human rights aspect is found in the definition of EMS which has traditionally provided urgent treatment to patients who suffer from injuries or sudden onset of illness. ${ }^{3}$ In other words, the core function of EMS is to safeguard one of the most fundamental human right to life. By ratifying the international and regional human rights documents, Finland for instance, has accepted to be bound by the legal norms obligating it to protect life and to guarantee the highest standard of health care available within its resources. These norms have then been transferred in the Constitution and clarified in detail by substantive legislation such as in the Health Care Act (Terveydenhuoltolaki, 1326/2010) and the Decree on Emergency Medical Service (Asetus Ensihoitopalvelusta, 585/2017).

Considering that EMS has a relatively strong legal basis in Finnish law, it seems inevitable to ask why EMS faces challenges in becoming recognized as a legal norm enshrined in the international human rights law. This paper answers the aforementioned question primarily through the Scandinavian way of legal thinking, frequently referred to as Scandinavian Legal Realism or the Scandinavian School of Thought. This approach has been selected because the traditional distinction between natural and positivist legal theories seems rather insufficient to provide a comprehensive answer to the research question. Despite being a legal norm, EMS is nevertheless attached inter alia with economic, societal and political aspects (Uusitalo, 2018a, p. 405; Uusitalo, 2018b, p. 206). Therefore, Scandinavian Legal Realism, which perceives law as a social phenomenon that cannot be isolated from the social context, seems to offer the most compatible and practically oriented grounds for the present analysis (Jorgensen, 1984; Hart, 1959). However, as no single legal theory can comprehensively explain the functions of legal norms, ideas emerging from Scandinavian Realism are supplemented with additional scholarly views and the historical aspects of human rights that can de facto enhance the understanding of Scandinavian legal thinking.

Essentially, this paper argues that the main reason that EMS fails to be recognized as a legal (human right) norm is because of its impersonalized nature. To clarify this hypothesis, EMS is generally of no concern to an individual until emergency medical care is needed. It is only after a personal experience that a person starts to consider the importance of EMS and to evaluate the compatibility of existing legal frameworks with personal and societal values. Actions to change the prevailing societal understanding of EMS are initiated when the current legislative basis is no longer perceived to correspond with what individuals perceive as fair and just. The aim of the paper is to clarify the theoretical background and the challenges of legal (human rights) norms, primarily through concrete examples, in order to better understand how the law and human rights operate in society. The analysis is applied both at a national level and in the international arena.

This paper is structured as follows. After the introduction, section two explains the main perceptions and the position of Scandinavian Legal Realism with respect to other legal theories regarding the question of what law is. Section three examines how Scandinavian legal thinkers perceive human rights in general. Elected examples of human rights issues are presented and analysed. Section four applies the theoretical observations from the previous sections to analyse the primary research question: why

\footnotetext{
2 See, for example, Article 25 of the Universal Declaration of Human Rights; Article 12 of the International Covenant on Economic, Social and Cultural Rights; Article 13 of the Revised European Social Charter.

${ }^{3}$ According to the Finnish law EMS is defined as "urgent treatment of patients who have suffered an injury or a sudden onset of an illness primarily outside of health care treatment facilities" (Terveydenhuoltolaki 1326/2010, art. 40(1))
} 
does EMS faces challenges to be regarded as a legal norm? Finally, section five summarizes the findings and offers concluding remarks.

\section{SCANDINAVIAN LEGAL REALISM ON THE DEFINITION OF LAW}

The questions of what law is, how legal norms operate and why individuals follow laws are by no means straightforward. Historically, discussions have evolved around the question of the interactions between sovereign and subservient, evaluating inter alia whether people must unquestioningly obey laws in every circumstance, or whether the governing power is in fact vested on people (see Kant, 1793; Rousseau, 1762). Regarding the essential nature of law, legal positivists such as Hans Kelsen perceived law as an isolated phenomenon which should be distinguished from any form of moral sentiment or politics, and is followed simply by virtue of being a norm that imposes negative sanctions (Somek, 2007, pp. 411-414; Kammerhofer, 2009, pp. 227-228). Others, such as H.L.A. Hart, drew a distinction between rules imposing legal obligations and rules conferring legal power. He understood that not all legal provisions are coercive in nature, but still believed in the ultimate rule of the legal system (Hart, 1986; Lon Fuller, 1964, p. 385; Payandeh, 2011, p. 974). Arguments against what can be referred to as "pure and isolated law" were presented by natural law theorists such as John Rawls and Jürgen Habermas. They understood law to stem from moral values and a moral sense of justice that human beings have by nature (Weithman, 2009, pp. 117-118; Khan, 2012, pp. 153154; Leeper, 1996, p. 139). This implies that a legal norm which does not reflect morality has de facto no legal value, and cannot even be a legal norm. The political theorist Carl Schmitt on the other hand, perceived law as nothing more than politics in which the monopoly has been granted to a lawmaker (Schmitt, 1929, pp. 19-25; Schmitt, 1932, p. 23; Berkmanas, 2010, p. 107). This represents a rather sceptical view with no positive validation in law. In this chaotic battle of contradictory views, the Scandinavian Legal Realism seems to offer a balancing settlement by combining differing perceptions of the law.

The Scandinavian Legal Realism, which is also frequently referred to as the Scandinavian School of Thought, was founded at the beginning of the $20^{\text {th }}$ century and is traditionally associated with four scholars. Axel Hägerström (1868 - 1939), a Swedish philosopher and Alf Ross (1899 - 1979), a Danish lawyer, are generally regarded as the founders of the Scandinavian way of legal thinking. Working with them were Hägerström's students, Anders Vilhelm Lundstedt (1882 - 1955) and Karl Olivecrona (1897 - 1980) (Bjarup, 2005, pp. 1-2; Eliasz and Jakubiec, 2016, pp. 107-109). Whilst each of these philosophers has slightly different interpretations of the metaphysics of law, the essential elements for understanding the law are more or less in agreement.

What makes this Scandinavian line of legal thinking appealing is its practical orientation. For Scandinavian thinkers, law is a socially constructed fact, and therefore needs to be interpreted in the societal context (Jorgensen, 1984, p. 2; Baaz, 2009, pp. 1011 ; Hart, 1959, p. 234). Interestingly, despite the fact that Scandinavian realists aimed to challenge the distorted perception of law represented by both positivist and natural legal theories, they ultimately reflected the elements from both schools of thought and from other political and moral philosophers (Bjarup, 2005, pp. 1-2; Eliazs and Jakubiec, 2016, p. 107). However, such concessions towards other theories do not decrease the

\footnotetext{
${ }^{4}$ It should be noted that American legal realism shares the same understanding of law being dependent on social factors. However, representing legal theory in a common law jurisdiction, American realism is more focused on courts and socio-economic factors affecting to them, whereas Scandinavian legal realists reflect civil law jurisdiction (see Pihlajamäki, 2004, pp. 470-472).
} 
importance of the Scandinavian Realism but rather they allow Scandinavians to offer a clearer perception of the law by combining various viewpoints and forming their own interpretations.

The main arguments and line of logic represented by Scandinavian Legal Realism can be summarized as follows:

1. It is not that a norm itself that has much value in reality. Instead, the importance is vested in the idea of the norm existing in people's minds (Schmidt, 1978, p. 10; Pattaro, 2009, pp. 540-542; Niemi, 2016, p. 34). It follows that a legal norm is only an abstract matter (an idea), having no practical meaning for an individual until it becomes a reality for them.

2. Individuals follow (the idea of) a legal norm because of their own moral sentiment of duty, fear of moral disapproval or sanctions, or because there is not sufficient motive to break the law (Schmidt, 1978, pp. 9-10; Jorgensen, 1984, pp. 2-5; Carty, 2003, pp. 822-824). Therefore the essential purpose of law is to direct a person's behaviour, and a mere feeling of being bound by law is sufficient to hinder illegal actions and make individuals comply with what is expected of them (Schmidt, 1978, pp. 13-20; Eng, 2011, p. 223; Holtermann, 2017, p. 30).

3. Those in power have a certain authority to influence a sense of right and wrong. $A$ preference for security and a fear of the unknown can restrain individuals from the challenging legislation (Schmidt, 1978, pp. 16-18; Spaak, 2014). However, because norms do not have a reality of their own but are constructed in the minds of individuals to reflect the feelings of society, it follows that in order for a norm to have legal validity, it must correspond with what is perceived as fair and just by the public (Jorgensen, 1984, p. 5; Carty, 2003, p. 826; Pattero, 2009, pp. 540-542; Holtermann, 2017, p. 30). Therefore the power of a lawmaker is not absolute, but must de facto represent the societal values.

The foundation of Scandinavian Legal Realism is therefore human beings and human conduct in society. In a sense, such a philosophical approach is not inherently unique. It has, for instance, been admitted that even in the sphere of egoism, each individual citizen is nevertheless a member of society (Marx, 1844, pp. 128-131). Therefore, every individual decision and action should be reflected in a societal context, i.e., how actions affect others and how others perceive one's actions (Mill, 1849, p. 145; Sartre, 1945, pp. 30-31; Parekh, 2004, p. 47). However, what differentiates Scandinavian legal realists from these (political) philosophers, is that instead of engaging merely in a socio-political analysis, Scandinavians sought to explain the functions of law and legal norms by utilizing moral perceptions and socio-political evaluations.

Interestingly enough, Scandinavian Realism reflects, at least to some extent, legal positivism by acknowledging the existence of legal norms (or the idea of a legal norm that binds us). However, by claiming that individuals do not follow the norm simply because it exists, but because the public has accepted it, Scandinavians concede towards a natural theory of law as well as moral philosophers. In fact, such a notion can be seen to reflect an inter alia utilitarian approach according to which, law itself cannot be a synonym for justice due to the possible existence of unjust laws, even though the ultimate goal of law should be to promote happiness (Mill, 1861, p. 139; Hayden, 2001, p. 118). Consequently, Scandinavian Realism combines legal positivism that emphasize the existence of (some form of) norm, with moral (utilitarian) philosophers and natural law theorists appraising an individual's sense of righteousness and morality, i.e., personal feelings contributing to individual's decision on obeisance of the law.

Essentially, whether a norm is followed because it has been codified in the legislation or because we merely feel a moral sense to comply with it, is irrelevant for Scandinavian realists. Instead, what is important is the collective understanding among 
individuals of what is regarded valuable enough to be followed. In contrast to natural law theorists, Scandinavian realists perceived law as more of an intangible phenomenon which has little importance to individuals in ordinary circumstances. In other words, what Scandinavians claim, is that individuals comply with the law more or less automatically, without any further moral appraisal, until they face injustice. What is regarded as injustice, on the other hand, derives from an individual's own values, attitudes, morals and prejudices (see Tamanaha, 2006, p. 1267). These factors, then, have a basis in historical and cultural heritage, which essentially explains why similar rules have different implementations depending on social context (Picker, 2011, p. 88; Eberle, 2011, p. 52). The similar logic of feeling bound, cultural context and the fear of moral disapproval, in fact applies equally at the national level among individuals and in the international arena to explain states' behaviour. Some states are more concerned about their international reputation and choose to comply with international norms simply to avoid "bad publicity" and because they perceive compliance to be the right thing to do. However, for some states, the feeling of being bound by common rules does not constitute sufficient grounds to adjust their conduct to correspond with international law. Thus, Scandinavian Legal Realism offers a practically oriented theory on law, according to which non-judicial determinants (and human factors) cannot be overlooked in the legal analysis of both national and international law.

\section{SCANDINAVIAN LEGAL REALISM APPLIED TO HUMAN RIGHTS}

Human rights form a branch of contemporary international law and are binding upon states either through ratification and implementation of international human rights treaties in accordance with the 1969 Vienna Convention on Law of Treaties, or because of customary international law. International human rights law, as we currently understand it, has its foundations in the 1948 Universal Declaration of Human Rights (UDHR) which was established in the aftermath of the terrible events of World War II. However, instead of being a mere codification of legal norms, human rights are de facto a formation of collective power representing our moral and political conceptions (see Lefort, 1986, pp. 261-263; Bagatur, 2014, p. 11; Keedus, 2011, p. 192). Human rights have a much longer history than conventional human rights law implies. Indeed, the rights that are currently guaranteed by the UDHR and other human rights treaties, in fact represent inter alia continuous historical failures to protect minorities as well as inhumane conditions and treatment of human beings. ${ }^{5}$ Throughout history, human beings have taken actions to demand changes when they have found something that does not comply with their understanding of rightness. In other words, our awareness of the right to have rights, as Hannah Arendt presents it, as well as our membership of a political society, have enabled the development of (contemporary) human rights law (Arendt, 1958, p. 296; Oman, 2010, pp. 285-286). It is therefore fair to say that human rights law has evolved not only through our attempts to reconcile ourselves with historical guilt, but also through dissatisfaction and feelings of injustice.

It should be noted that, since there is no consensus on what law actually is, no agreement on the philosophical basis of human rights has been reached (Payandeh, 2011, p. 969; Cambell, 2011, p. 455; Bittner, 2015, pp. 73-74). Human beings are, of course, regarded as possessing rights simply by virtue of being human (Tasioulas, 2015, p. 50;

\footnotetext{
${ }^{5}$ In fact, the $13^{\text {th }}$ century King of England limited his powers to infringe the rights of his sub servants by signing the Magna Carta. The anti-slavery movement, for instance, took place from the $17^{\text {th }}$ century to the $19^{\text {th }}$ century. Similarly, the French revolution (1789) and its American equivalent (1776) are classical examples of events in which the people were unsatisfied with how they were treated (see more in Neier, 2012, p. 2012; Moyn, 2008, pp. 22-25; Charvet and Kaczynska-Nay, 2008, pp. 72-74; Parekh, 2004, pp. 43-44).
} 
Pogge, 1995, pp. 187-191). However, at the same time the extent to which human rights have expanded, challenges human rights to be perceived purely as a source of natural law. Surely it is fair to claim that we should preserve the right to life by refraining from killing each other because of our moral perception, regardless of the existence or absence of a written criminal code. However, the assumption that individuals have a right to highly professional medical assistance and access to in vitro fertilization (IVF) treatment simply by virtue of our humanity, seems rather far-reaching, even though new technologies have enabled such rights (Tasioulas, 2015, p. 61). Thus, by simply applying the natural legal theory to human rights, the scope of our rights would be deemed much narrower than we have become accustomed to. The codification of rights allows us to expand our perceptions alongside the developments in our societies. However, even written legal provisions are meaningless without social contextualization.

Whilst Scandinavian legal realists have not discussed human rights per se, the concept of a "legal right" has been analysed, in particular by Olivecrona and Ross. Olivecrona, for example, regarded a right to be nothing more than an imaginary power, whereas for Ross, a right was merely "a technical tool of presentation" (see Spaak, 2014, p. 265; Bix, 2009, p. 112). However, despite their noble characterization of representing our historical guilt and dissatisfactions, human rights are essentially comparable to any other legislative norm, and can thus be analysed by applying the general notions of law presented by Scandinavian legal realists. The fact that human rights do not possess any magical characteristics over other legal rules can be explained by the idea that whilst international human rights today form an integral part of our legal systems, such norms have (generally) no legal validation at a national level without implementation (MeckledGarcia, 2015, p. 304). The rules of international treaty law are not limited to international human rights per se but they apply de jure equally to all international agreements. Consequently, the nature of legal provision guaranteeing freedom of expression under Article 19 of the International Covenant on Civil and Political Rights (1966) does not inherently differ from the norm conferring ships the right to innocent passage through the territorial sea in accordance with Article 17 of the United Nations 1982 Convention on Law of the Sea.

However, it is important to note the difference between international human rights law and human rights at national level. The former is universal at the theoretical level as all international and regional human right treaties are de facto attributable to the UDHR, declaring equal and inalienable rights to all and reflecting the language of moral philosophy (Tesón, 1985, p. 382; Li, 1996, pp. 397-408; Buchanan, 2015, p. 244). However, international human rights without any social contextualization are simply too abstract and vague to have any practical legal validation and can be no more than a moral framework which helps to value states' conduct in the international arena (Renzo, 2015, pp. 570-576; Monshipouri, 2001, p. 372; Nelken, 1984, p. 170). Therefore, from the perspective of ordinary individuals, human rights gain their legal power through implementation, but at the same time they seem to lose their legal importance of being human rights as they are being transferred to mere legal norms. To clarify such a hypothesis, under normal circumstances people in Finland, for example, do not wake every morning thinking that they have the right to life and personal integrity - despite its constitutional protection which has been expanded further in the criminal code (39/1889) criminalizing inter alia homicides and bodily injuries. Instead, it is only after one's life has been endangered by a perpetrator, either directly or indirectly, that an individual becomes concerned with such a right.

What Scandinavian Legal Realism contributes to the explanation of human rights is the recognition of legal norms (or ideas of legal norms) being social factors which reflect an individual's perception of rightness. People do not respect the norms merely 
because they are written laws, but because compliance is expected from them by other members of society, and because the public perceives no value in not obeying them. In a sense, human rights, even at the national level, appear to be more or less abstract or selfevident norms. These norms are of no concern to people until the idea of a norm, such as the right to life, actualizes in reality, e.g. surviving a car accident. Furthermore, due to social contextualization, or cultural diversity, human rights have different effects in different societies (Raz, 2015, p. 229). That is why gender-neutral marriages, for instance, are accepted in every Nordic country, while same-sex relationships are still illegal in Uganda and even carry the death penalty in Sudan (Amnesty International, 2018a). Similarly, wearing the burqa in Muslim countries reflects a religious and cultural context whereas prohibiting them in Denmark represents a different social environment (Margolis, 2018; The Independent, 2018). Such examples not only illustrate how cultural diversity affects the implementation of human rights, but also elucidate the Scandinavian legal realists' perceptions on the de facto way that the law functions.

As Scandinavians explain it, law is by no means an absolute and unchallengeable representation of sovereign will. Rather it is the existence of norms (in people's minds; i.e. an idea of a norm) that confers authorities the de facto power (Pattero, 2009, p. 542; Spaak, 2014, pp. 267-268). Actions are thus initiated when the idea of how law should be does not correspond with what law is. For example, a successful campaign promoting gender-neutral marriage in Finland was launched in 2013. An act permitting same-sex couples to register their partnerships, but not to enter into marriage, was perceived by the public as discriminatory and unjust (Tahdon2013, 2013a; Hallituksen esitys, 2015). In addition to the general public, a large number of organizations, companies and celebrities stated their support for the campaign (Tahdon2013, 2013b). The enhanced Marriage Act came into force in March 2017. The campaign proves the Scandinavian theory of the importance of values in social context since not everyone who supported the campaign was personally directly affected by the unjust law (i.e. a discriminatory Marriage Act). Instead, it was a sense that the legislation in force contradicted one's inner value judgment and understanding of equality that enabled both natural and legal persons to act.

The Scandinavian legal realists' perceptions on how the law functions and why (human rights) legislation is changed can be seen in the philosophy of Hannah Arendt (1906-1975) and Jacques Ranciére (b. 1940). Similarly to Scandinavian realists who valued the socially constructed idea of a norm, Arendt and Ranciére also focused on social contextualization and the power of a group in their explanation of human rights. For them, human rights do not belong to everyone simply by virtue of humanity, but because rights are demanded and fought for by those who lack those rights (Arendt, 1958, pp. 279, 301-302; Ranciére, 2010, pp. 67-68; Van der Hemel, 2008, p. 18). In other words, what Arendt and Ranciére essentially claim is that we have an idea of a norm (i.e. an idea of the right to have rights), something that we perceive to have a right to because that right corresponds with our feelings of justice and fairness, e.g. gender-neutral marriage. When our idea of rightness does not correspond with the rights that we have (our de jure rights), we engage in actions to cause what Ranciére referred as dissensus in order to achieve the change that reflects our understanding of the rights we believe we are entitled to. Legislators respond to our demands because they represent a formation of our social power and ability to cause political struggle, and/or because lawmakers share similar perceptions (Lefort, 1986, pp. 261-263; Bagatur, 2014, p. 11; Oman, 2010, p. 287; McLoughlin, 2016, pp. 315-316).

In this regard, banning burqas in Denmark cannot be regarded wrong per se as this Scandinavian country does not have an intensive religious or cultural attachment with Islam. What matters more is the notion that Scandinavia has always been regarded 
among the safest regions in the world, ${ }^{6}$ and therefore security has been more or less selfevident for the Scandinavians. However, terrorist attacks such as the 2017 Stockholm car attack or the stabbing in Turku (Finland) four months later ${ }^{7}$ have demonstrated the fact that security is not an intangible and absolute value which cannot be interfered with. However, it is precisely because this long-existing societal feeling of security was in danger of being lost that Danish people felt compelled to act. Since Islam is not a widely represented religion in Scandinavia, the public security was valued over the freedom of religion (and expression). Notably, Denmark did not restrict or prohibit freedom of religion, but merely modified it to fit and reflect better Danish societal values of security. ${ }^{8}$ Similarly, at the international level, the Denmark's idea of security exceeds moral approval to which it was subjected to by international human right organizations (Margolis, 2018; Amnesty International, 2018b). Essentially, such a situation authenticates the perception according to which human rights gain their validation at the national level.

\section{SCANDINAVIAN LEGAL REALISM EXPLAINS WHY EMS FACES CHALLENGES}

One of the main reasons for EMS facing challenges in being recognized as a legal human rights norm, is linked to the overall problem of international law being subject to power politics and state interests. While the UDHR is repeatedly referred to as a basis for modern human rights, in practice the document lacks judicial effect. The legally binding international human rights law created a distorted perception of socio-economic rights primarily associated with communism (Tomuschat, 2003, p. 1). This led to an artificial, unnecessary and impractical categorization of human rights (see Gould, 2015, p. 189; Clayes, 2015, pp. 233-234). This misperception, according to which social and economic rights should be separated from civil and political ones (since no interconnection is understood to exist between them), has unfortunately been repeated time after time at the national level.

It is true that not all human rights are equal in their meaning. For example, unlike the traditional perception of the right to life including the prohibition to kill, ${ }^{9}$ the right to EMS does not per se demand any actions from right holders. Human beings refrain from killing each other either because of the legal norm that has already been codified in the national law and/or because it is (morally) expected that we should not kill each other. Similarly, the right to marry a same-sex partner or the preservation of one's security, are concerns that have more or less a direct and concrete effect on individuals. EMS, on the other hand, is a right which imposes duties on the state, but roughly speaking does not provoke or confer any behavioural norms to individuals. Therefore, the explanation that Scandinavian legal realists would give to the question of why EMS fails to be recognized

\footnotetext{
${ }^{6}$ The most recent Global Peace Index report placed Denmark the $5^{\text {th }}$ safest country in the world, Iceland holding the first place and other Scandinavian countries (i.e., Finland, Sweden and Norway) accommodating the positions of 14, 15 and 17 (see Institute for Economics \& Peace, 2020).

7 In the 2017 Stockholm car attack, the perpetrator hijacked a van and drove into the public killing five and injuring tens of bystanders. In Turku, a perpetrator stabbed two victims to death and injured several others. In both cases the perpetrators had expressed their support to ISIS (Islamic State in Iraq and Syria), and were initially found guilty of terrorist crimes. See more in Stockholms Tingsrätt (District Court of Stockholm), Dnro B 4708-17, 7 July 2018; Varsinais-Suomen käräjäoikeus (District Court of Southwest Finland), Dnro 18/125884, 15 June 2018

${ }^{8}$ It should also be noted that according to the international human rights law, the freedom of religion and freedom of expression are not absolute rights but can de jure be subject to limitations inter alia on the grounds of public safety or national security. See, for example, Convention for the Protection of Human Rights and Fundamental Freedoms (1950), art. 9(2) \& 10(2); International Covenant on Civil and Political Rights (1966), art. 18(3) \& 19(3)

${ }^{9}$ See, for example, the cases of ECtHR Osman vs United Kingdom, app. no. 23452/94, 28 October 1998, and ECtHR, Mahmut Kaya v. Turkey, app. no. 22535/93, 28 March 2000.
} 
as a legal (human rights) norm is that, as important as EMS is in safeguarding the right to life, under normal circumstances individuals are not cornered with EMS because they lack any personal attachment to it. In other words, when individuals have not been associated with EMS in practice, the abstract right (an idea of having a right) to EMS has not materialized or become personalized for them. ${ }^{10} \mathrm{It}$ is only after an individual faces the need for, or becomes aware of emergency medical care, that the abstract idea of the right to EMS actualizes in reality and invokes an evaluation of whether the existing legal framework corresponds with the individual's perception of how the law should be.

In this regard, it is irrelevant that socio-economic rights have a different nature from civil and political ones, because the Scandinavian logic applies to all human rights and legal norms in the same way. Instead, it is the perception of individuals that diverts rights from each other. For example, the right to education, despite being a socioeconomic right, touches upon every family with children, whereas an individual may never exercise the right to peaceful assembly even though it is one of the core first-category human rights. The failure to perceive EMS as a human right, or even a legal norm, occurs precisely because it is too abstract in appearance for individuals to be concerned with. This Scandinavian notion applies to politicians and legislators as well. For instance, Article 2(1) of the International Covenant on Economic, Social and Cultural Rights (ICESCR), lays down the core minimum requirements that the state must undertake in order to guarantee the right to health under Article 12 of the Covenant. However, Article 12 has been drafted in a rather abstract way calling for the right of everyone to enjoy the highest attainable standards of health and obliging the state to take progressive steps to ensure availability of all medical services and medical attention in the event of sickness, but the article is nevertheless silent regarding an explicit right to EMS. Indeed, the right to health and health care as enshrined in Article 12 of ICESCR, has been described as incoherent and unspecific (Wolff, 2015, pp. 491-492; Brownlee, 2015, p. 502). Because of a generalized wording of the said article, and an absence of a specific reference to EMS, it is understandable that the legislators and politicians may fail to acknowledge the essential importance of EMS as being a human right (or even a legal norm) since the right to EMS is only an abstract idea to them, with no practical meaning in reality.

The above-mentioned claim is well-illustrated in the judgment issued by the Administrative Court of North Finland in which two applicants unsuccessfully challenged the legality of the Hospital District's decision to remove two ambulances from sparsely populated areas. ${ }^{11}$ The applicants filed the claim because they lived in the affected areas and were therefore affected by the decision despite the absence of an actual incident. Applying Scandinavian Legal Realism to explain these actions, the rearrangement of the location of ambulances made the applicants realize that their sense of security (i.e. the idea of EMS being able to respond without undue delays) was compromised. Actions were eventually initiated because the Hospital District's new plan did not reflect the applicants' feelings of justice and fairness. From the legal point of view, the failure of the claim, on the other hand, resulted from the applicants' failure to argue the case from a constitutional (human rights) perspective which would have enabled a stronger emphasis on a properly functioning EMS system (i.e. the right to EMS) and the right to life. ${ }^{12}$ Another significant factor contributing to the unsatisfactory result for the applicants was the fact that neither the Hospital District nor the general population recognized the importance of

\footnotetext{
${ }^{10}$ In fact, health care in general is perceived as a need-based right which is exercised only when there is a medical problem (Nickel, 2015, p. 159).

11 See Oulun hallinto-oikeus (2014). Päätös dnro 14/00053/1; and Administarive Court of Oulu (2014). Decision dnro 14/00053/1

12 The case was sought to challenge the administrative laws, including the Health Care Act and Local Governmental Act, and made no references to human rights.
} 
the issue because the removal of ambulances from these areas had no direct effect on them. Reasoning, placing a wide emphasis on economic determinants and costeffectiveness was in accordance with the Administrative Court's jurisdiction, and the judgment per se contained no legal deficiencies. However, the case might have reached a different judgment if it had been litigated from a different perspective in a different court, or if the applicants had generalized the issue and invoked a wider population to acknowledge injustice of the Hospital District's decision.

By establishing some legal provisions concerning EMS at the national level, Finland has de jure satisfied its obligations under international treaty law, even though the extent of the implementation can be debated. From the Scandinavian perspective, legislators have exercised their power not only to comply with international law, but also to influence the sense of right and wrong. Because of the generally impersonalized nature of EMS (i.e. the fact that not everyone needs to invoke their right to EMS), the majority of individuals are satisfied with the existing legal framework (the idea of EMS) without facing the need to further evaluate that idea. However, as Scandinavians and scholars like Jacques Ranciére and Alain Badiou believe, law is not a representation of an absolute sovereign power, but rather a creation of on-going negotiations which result inter alia from people's feelings (Blechman, Chari and Hasan, 2012, pp. 163-164; Pettersson, 2011, p. 265; Banaker, 2010, p. 24). It follows that EMS becomes a defendable human right when it receives a personalized interest, when someone's idea of EMS does not match with the reality. A change therefore occurs as a result of our actions (Gündogdu, 2014, p. 370). Since the law is inherently a social phenomenon, a sole individual has relatively little chance to affect a change, the chosen actions depend on the position and perception of others as well. Therefore, in order to ensure the availability of ambulances in sparsely populated areas, or to abolish dead zones in the EMS helicopters' operational areas, one must transfer the abstract idea of EMS to the societal reality through personalization by appealing to peoples' emotions (Rorty, 1993, pp. 254-255; Hunt, 2007, p. 26; Faralli, 2014, p. 59). When the legal norm of EMS is no longer a mere abstract idea but has a personal attachment, either through one's own experience of injustice or as a result of becoming aware of existing unfairness, individuals no longer fear sanctions or moral disapproval from others while engaging in actions (of negotiations, disturbances, demonstrations etc.) to change the prevailing system. This is because their actions reflect the wider societal values.

The equivalent logic of an impersonalized idea of EMS applies to the state as well. The state is not concerned with EMS if no self-interest is at stake (Uusitalo, 2018c, pp. 101-102). As long as the state has implemented at least some health care provisions and has some form of EMS in place, the international community, the UN Committee on Economic, Social and Cultural rights for example, should have no reason to interfere with the state's internal affairs in that regard or express any moral disapproval. When individuals perceive EMS more as an abstract idea rather than an actual norm, no dissatisfaction from the public would be expected either. It follows that Finland, for example, could postpone the establishment of new HEMS bases because their absence is not regarded to have any (wide) capability of disturbing those in power. However, just as a legislator has the power to direct our behaviour, the Scandinavian Legal Realists would identify with the claim that it should be in public interest to promote fairness, and prevent any dissatisfaction that might escalate (Finnis, 2011, pp. 33-34). In relation to the Scandinavian logic, it is important to note that it is not the injustice itself that is capable of causing disturbances, but rather the feeling (an idea) of injustice. It follows that EMS and the right to it is a matter of collective will - a form of a traditional social contract enabling those in power to maintain power because the public perceives no reason to dethrone them (Bagatur, 2014, p. 11; Rousseau, 1762). Furthermore, in the globalized and 
highly interconnected world where states are expected to hold certain moral standards in relation to human rights, the feeling of injustice can emerge externally (Monshipouri and Welch, 2001, p. 372; Kistner, 2014, p. 122). This can cause dissensus in the international arena if other states or human rights organizations express their moral disapproval of Finland's failures regarding EMS. Finland may then comply with these external influences if it regards them to have valid grounds, or it may disregard them due to differences in opinion on the idea of EMS.

Since the government wishes to stay in power and it is in the state's interest to avoid any external influence, implementation of EMS legislation (and of any laws) should essentially reflect the moral standards and evaluations of what is perceived as fair and just. In this regard, the determining factor is not whether the right to EMS is actually and explicitly codified in the international human rights treaties, but how its implementation and actualization from an abstract idea into reality is understood to correspond with the values of a specific society.

\section{CONCLUDING REMARKS}

Scandinavian Legal Realism was founded at the beginning of the $20^{\text {th }}$ century to challenge the distorted battle on the metaphysics of law between natural law theorists and legal positivists. Whereas (roughly speaking) natural theorists emphasize our moral consciousness as a directing factor to explain the essence of law, and legal positivists believe only in the written norms, for Scandinavian thinkers the validity of the legal norm does not rely on the norm itself, but on the idea of a norm. Essentially, Scandinavian Legal Realism perceives law as an abstract phenomenon which gains its value through actualization. This occurs either when the matter touches upon us directly, or when the existing legal norm is perceived not to correspond with our idea of what the public regards to be just and fair. What primarily distinguishes Scandinavian Legal Realism from natural or positivist legal theorists, is the incorporation and greater emphasis of human feelings to explain the legal metaphysics.

The Scandinavian way of legal thinking is in fact quite successful in explaining the problems of contemporary human rights law. Since human rights are now codified in international conventions and implemented in national legislation, it is irrelevant to engage in the discussion about the essential metaphysics of the rights. Instead, what Scandinavian perception offers to current human rights law is the notion that the law and its implementation is always affected by societal determinants. Because of these societal variations, the same human rights have different meanings at national levels. This explains why gender-neutral marriage, for instance, is legalized in one state and criminalized in another. Furthermore, as the Scandinavian thinkers would explain it, as long as human rights are implemented to correspond with the general perceptions of rightness, justice and fairness in the given society, these legal norms are regarded more or less as abstract (or self-evident) ideas which, under normal circumstances, do not impose concerns on human beings. However, individuals start to evaluate the validity of a legal norm when it is, for some reason, transferred into reality. This line of logic is also applicable to rationalize why emergency medical service (EMS) faces challenges to be recognized as a legal norm.

Despite being a sub-category of the internationally recognized human right to health and thereby enjoying some form of implementation at the national level, EMS still seems to be perceived as an economic expense or a political question rather than a legal norm. Applying the Scandinavian Legal Realism, this misperception is caused by the impersonalized nature of EMS - an abstract idea of the right to EMS that has not been actualized. In other words, even though EMS is essentially designed to safeguard the 
fundamental human right to life by ensuring urgent treatment in life-threatening situations, individuals are not concerned about the placement of ambulances or EMS helicopters until they actually face the need of emergency care. It follows that EMS becomes a defendable legal norm only when it receives a personalized interest from someone and that person can convince others of the existing injustice.

\section{BIBLIOGRAPHY:}

Amnesty International (2018a). Mapping Anti-Gay Laws in Africa. Retrieved from: https://www.amnesty.org.uk/lgbti-lgbt-gay-human-rights-law-africa-ugandakenya-nigeria-cameroon (accessed on 03.07.2020).

Amnesty International. (2018b). Face Veil Ban Discriminatory Violation of Women's Rights. Retrieved from: https://www.amnesty.org/en/latest/news/2018/08/denmark-face-veil-ban-adiscriminatory-violation-of-womens-rights/ (accessed on 03.07.2020).

Arendt, H. (1958). The Origin of Totalitarism. London: A Harvest Book, Harcourt Brace \& Company.

Baaz, M. (2009). Introducing Scandinavian Legal Realism to the English School of International Relations. BISA's Annual Conference 2009.

Bagatur, S. (2014). Towards a Democratic Conception of Human Rights. Theoria and Praxis, 2(1). ISSN: 2291-1286.

Banaker, R. (2010). Law, Rights and Justice in Late Modern Society: a Tentative Theoretical Framework. In: Banakar, R. (ed.), Rights in Context: Law and Justice in Late Modern Society (2010, pp. 19-37). Surrey: Ashgate. ISBN-13: 978-1-40940740-9.

Berkmanas, T. (2010). Schmitt v. (?) Kelsen: The Total State of Exception Posited for Total Regulation of Life. Baltic Journal of Law and Politics, 3(2), 98-111. DOI: 10.2478/v10076-010-0012-x.

Bix, B. H. (2009). Ross and Olivecrona on Rights. Australian Journal of Legal Philosophy, 34, 103-119.

Bittner, B. (2015). On Invoking Human Rights When There Aren't Any. In Kaul, S. and Kim, D. (eds.), Imaging Human Rights (2015, pp. 69-81), Berlin: De Gruyter, Berlin. ISBN: 978-3110376197.

Bjarup, J. (2005). The Philosophy of Scandinavian Legal Realism. Ratio Juris, 18(1), 115.

DOI: 10.1111/j.1467-9337.2005.00282.x.

Blechman, M., Chari, A., and Hasan, R. (2012). Human Rights are the Rights of Infinite: An Interview with Alain Badiou. Historical Materialism, 20(4), 162-186. DOI: 10.1163/1569206X-12341235.

Brownlee, K. (2015). Do We Have a Human Right to the Political Determinants of Health?. In: Cruft, R., Liao, M. and Renzo, M. (eds.), Philosophical Foundation of Human Rights (2015, pp. 502-514). New York: Oxfrod University Press. ISBN 9780199688623.

Buchanan, A. (2015). Why International Legal Human Rights?. In: Cruft, R., Liao, M. and Renzo, M. (eds.), Philosophical Foundation of Human Rights (2015, pp. 244-262). New York: Oxford University Press. DOI:10.1093/acprof:oso/9780199688623.003.0014.

Cambell, T. (2011). Parliamentary Review with Democratic Charter of Rights. In: Cambell, T., Ewing, K. D., and Tomkins, A. (eds.), The Legal Protection of Human Rights: Sceptical Essays (2011, pp. 453-471), New York: Oxford University Press. DOI:10.1093/acprof:oso/9780199606078.003.0022. 
Carty, A. (2003). Scandinavian Realism and Phenomenological Approaches to Statehood and General Custom in International Law. European Journal of International Law, 14(4), 817-841. DOI: 10.1093/ejil/14.4.817.

Charvet, J. and Kaczynska-Nay, E. (2008). The Liberal Project and Human Rights: The Theory and Practice of a New World Order. Cambridge: Cambridge University

Press.

DOI: $10.1017 / C B 09780511755972$.

Clayes, G. (2015). Socialism and the Language of the Rights: the Origins and Implications of Economic Rights. In: Slotte, P. and Halme-Tuomisaari, M. (eds.), Revisiting the Origins of Human Rights (2015, pp. 206-234). Cambridge: Cambridge University Press. ISBN: 978-1-107-10764-9.

Eberle, E. J. (2011). The Methodology of Comparative Law. Roger Williams Law Review, 16(51), 51-72.

Eliasz, K., and Jakubiec, M. (2016). The Vienna Circle and Uppsala School of Philosophical Inspiration for the Scandinavian Legal Realism. Semina Scientarium, 15, 107-123. DOI: http://dx.doi.org/10.15633/ss.1771.

Eng, S. (2011). Lost in the System or Lost in Translation? The Exchanges between Hart and Ross. Ratio Juris, 24(2), 194-246. DOI: https://doi.org/10.1111/j.14679337.2011.00482.x.

Faralli, C. (2014). Law as Fact. Revus, 24, 57-67. DOl: https://doi.org/10.4000/revus.3001.

Finnis, J. (2011). Human Rights and Common Good: Collected Essays, Volume III. New York: Oxford University Press.

DOI:10.1093/acprof:oso/9780199580071.001.0001.

Fredman, S. (2008). Human Rights Transformed: Positive Rights and Positive Duties. New York: Oxford University Press. DOI:10.1093/acprof:oso/9780199272761.001.0001.

Gould, C. C. (2015). A Social Ontology of Human Rights. In: Cruft, R., Liao, M. and Renzo, M. (eds.), Philosophical Foundation of Human Rights (2015, pp. 177-195). New York: Oxford University Press. DOI:10.1093/acprof:oso/9780199688623.003.0010.

Gündogdu, A. (2014). A Revolution in Rights: Reflections on Democratic Invention of the Rights of Man. Law, Culture and Humanities, 10(3), 367-379.

DOl: https://doi.org/10.1177/1743872112459034.

Hallituksen esitys eduskunnalle eräiksi avioliittolain muutoksen edellyttämiksi lainmuutoksiksi (2015). (Government's Proposal for the Parliament to Change the Marriage Law), HE 65/2015.

Hart, H.L.A. (1959). Scandinavian Realism. Cambridge Law Journal, 17(2), 133-140. DOI: https://doi.org/10.1017/S0008197300007650.

Hart, H.L.A. (1983). Essays in Jurisprudence and Philosophy. Oxford: Oxford University Press. ISBN: 9780198253884.

Hayden, P. (2001). The Philosophy of Human Rights. St. Paul: Paragon. ISBN-13: 978-1557787903.

Holtermann, J.V.H. (2017). A Straw Man Revisited: Resettling the Score between H. L. A. Hart and Scandinavian Legal Realism. Santa Clara Law Review, 57(1), 1-41.

Hunt, L. (2007). Inventing Human Rights: A History. New York: W.W. Norton \& Company. ISBN-13: 978-0393331998.

Institute for Economics \& Peace. (2020). Global Peace Index 2020: Measuring Peace in a Complex World. Sydney. Retrieved from: http://visionofhumanity.org/reports (accessed on 03.07.2020) 
Jorgensen, S. (1984). Scandinavian Legal Philosophy. Bulletin of the Australian Society of Legal Thinking, 8(2), 2-18.

Kammerhofer, J. (2009). Kelsen - Which Kelsen? A Reapplication of the Pure Theory to International Law. Leiden Journal of International Law, 22, 225-249.

Kant, I. (1793). The Principles of Political Right. In: Hayden, P. (ed.), The Philosophy of Human Rights (2001, pp. 110-117). St. Paul: Paragon, 112-113. ISBN-13: 9781557787903.

Keedus, L. (2011). 'Human and Nothing But Human': How Schmittian is Hannah Arendt's Critique of Human Rights and International Law?, History of European Studies, 37(2), 190-196. ISSN: SSN0191-6599.

Khan, G. (2012). Politics and Morality in Habermas' Discourse of Ethics. Philosophy and Social Criticism, 38(2), 149-168. DOI: https://doi.org/10.1177/0191453711427254.

Kistner, U. (2014). A Politics of Human Rights - the Right to Rights as Universal Right to Politics?, Acta Academica, 46(3), 122-133, p. 122. ISSN 0587-2405.

Leeper, R. V. (1996). Moral Objectivity, Jürgen Habermas's Discourse Ethics, and Public Relations. Public Relations Review, 22(2), 133-150. ISSN: ISSN-0363-8111.

Lefort, C. (1986). The Political Forms of Modern Society: Bureaucracy, Democracy and Totalitarism. The MITT Press. ISBN: 9780262620543

Li, X. (1996). Asian Values and Universality of Human Rights. In: Hayden, P. (ed.), The Philosophy of Human Rights (2001, pp. 397-408). St. Paul: Paragon. ISBN-13: 9781557787903.

Lon Fuller, L. (1964). The Morality and Law. In: Hart, H.L.A. (ed.), Essays in Jurisprudence and Philosophy (1983, pp. 343-364). New York: Oxford University Press. DOI:10.1093/aprof:oso/9780198253884.001.0001.

Mansikka, H. (2018). Sote-uudistus saattaa tuoda lääkärihelikopterin myös KaakkoisSuomeen, nyt tilanne perustuslain vastainen. Etelä-Saimaa, 24 March 2018.

Margolis, H. (2018). Denmark's Face Veil Ban Latest in Harmful Trend: Restrictions Discriminate against Muslim Women. Human Rights Watch. Retrieved from: https://www.hrw.org/news/2018/06/01/denmarks-face-veil-ban-latest-harmfultrend (accessed on 03.07.2020).

Marx, K. (1844). On the Jewish Question. In: Hayden, P. (ed.), The Philosophy of Human Rights (2001, pp. 127-135), St. Paul: Paragon. ISBN-13: 978-1557787903.

McLoughlin, D. (2016). Post-Marxism and the Politics of Human Rights: Lefort, Badiou, Agamben, Ranciére. Law Critique, 27, 303-321. DOl: 10.1007/s10978-016-91770 .

Meckled-Garcia, S. (2015). Specifying Human Rights. In: Cruft, R., Liao, M. and Renzo, M. (eds.), Philosophical Foundation of Human Rights (2015, pp. 300-315), New York: Oxford University Press. ISBN: 9780199688630.

Mill, J. S. (1859). On Liberty. In: Hayden, P. (ed.), The Philosophy of Human Rights (2001, pp. 143-146), St. Paul: Paragon. ISBN-13: 978-1557787903.

Mill, J. S. (1861). Utilitarism. In: Hayden, P. (ed.), The Philosophy of Human Rights (2001, pp. 137-143), St. Paul: Paragon. ISBN-13: 978-1557787903.

Monshipouri, M. and Welch, C. E. (2001). The Search for International Human Rights and Justice: Coming to Terms with New Global Realities. Human Rights Quarterly, 23(2), 370-401. DOI: 10.1353/hrq.2001.0020.

Moyn, M. (2008). The Last Utopia: Human Rights in History. Cambridge: Harvard University Press. ISBN 9780674064348.

Neier, A. (2012). The International Human Rights Movement: A History. Princeton: Princeton University Press, Princeton. ISBN: 9780691135151. 
Nelken, D. (1984). Law in Action or Living Law? Back to the Beginning in Sociology of Law. Legal Studies, 4(2), 157-174. DOI: https://doi.org/10.1111/j.1748121X.1984.tb00439.x.

Nickel, J. W. (2015). Personal Desert and Human Rights. In: Cruft, R., Liao, M. and Renzo, M. (eds.), Philosophical Foundation of Human Rights (2015, pp. 153-165). New York: Oxford University Press. ISBN: 9780199688630.

Niemi, M. (2015). The Influence of Jurisprudential Theories on Legal Dogmatics in Finland in the Area of Civil Law. Revista Direito Mackenzie, 9(1), 27-45. ISSN: 2317-2622.

Oman, N. (2010). Hannah Arendt's Right to Have Rights: A Philosophical Context of Human Security. Journal of Human Rights, 9(3), 279-302. DOI: $10.1080 / 14754835.2010 .501262$.

Parekh, S. (2004). A Meaningful Place in the World: Hannah Arendt on the Nature of Human Rights. Journal of Human Rights, 3(1), 41-52. DOI: 10.1080/1475483042000185215.

Pattaro, E. (2009). From Hägerström to Ross and Hart. Ratio Juris, 22(4), 532-548. DOI: 10.1111/j.1467-9337.2009.00439.x.

Pettersson, J. (2011). Rethinking Political Subjectification: Equality Beyond a Community of Sameness. Distinction: Scandinavian Journal of Social Theory, 12(3), 255-269. DOI: https://doi.org/10.1080/1600910X.2011.614814.

Payandeh, M. (2011). The Concept of International Law in the Jurisprudence of H. L. A. Hart. The European Journal of International Law, 21(4), 967-995. DOI: https://doi.org/10.1093/ejil/chq065.

Picker, C. B. (2011). Comparative Law Methodology \& American Legal Culture: Obstacles and Opportunities. Roger Williams University Law Review, 16(86), 8699.

Pihlajamäki, H. (2004). Against Metaphysics in Law: the Historical Background of American and Scandinavian Legal Realism Compared. The American Journal of Comparative Law, 52 469-488. ISSN: 0002-919X.

Pogge, T.W. (1995). How Should Human Rights Be Conceived?. In: Hayden, P. (ed.), The Philosophy of Human Rights, (2001, pp. 187-211), St. Paul: Paragon. ISBN-13: 978-1557787903.

Ranciére, J. (2010). Dissensus on Politics and Aesthetics. London: Continuum International Publication Group, London. ISBN-13: 978-1472583550.

Raz, J. (2015) Human Rights in the Emerging New World Order. In: Cruft, R., Liao, M. and Renzo, M. (eds.), Philosophical Foundation of Human Rights (2015, pp. 217-231). New York: Oxford University Press. DOI:10.1093/acprof:oso/9780199688623.003.0012.

Renzo, M. (2015). Human Needs, Human Rights. In: Cruft, R., Liao, M. and Renzo, M. (eds.), Philosophical Foundation of Human Rights (2015, pp. 570-587). New 
York: Oxford University Press.

DOI:10.1093/acprof:oso/9780199688623.003.0033.

Rorty, R. (1993). Human Rights, Rationality and Sentimentality. In: Hayden, P. (ed.), The Philosophy of Human Rights (2001, pp. 241-257). St. Paul: Paragon. ISBN-13: 978-1557787903.

Rousseau, J-J. (1762). The Social Contract. New York: Oxford University Press. ISBN: 9780199538966.

Sartre, J-P. (1945). Existentialism \& Humanism. London: Methuen. ISBN-13: 9780413776396.

Spaak, T. (2014). A Critical Appraisal of Karl Olivecrona's Legal Philosophy. Basel: Springer. ISBN 978-3-319-06167-2.

Schmidt, F. (1978). The Uppsala School of Legal Thinking. Stockholm: Almqvist \& Wiksell International.

Schmitt, C. (1929). The Concept of Political. Chicago: University of Chicago Press. ISBN13: $978-0226738925$.

Schmitt, C. (1932). Legality and Legitimacy. Durham: Duke University Press. ISBN: 978-08223-3174-2.

Somek, A. (2007). Kelsen Lives. The European Journal of International Law, 18(3), 409451, p. 411-414. DOI: https://doi.org/10.1093/ejil/chm028.

Sosiaali- ja terveysministeriö (2018). Työryhmä Selvittää Lääkärihelikopterien Uusien Tukikohtien Sijoituspaikkakunnat. Helsinki: Ministry of Social Affairs and Health. (Ministry of Social Welfare and Health. (2018). Working Group Established to Determine the Geographical Bases for New HEMSs). Retrieved from: https://stm.fi/-/tyoryhma-selvittaa-laakarihelikopterien-uusien-tukikohtiensijoituspaikkakunnat (06.07.2020).

Tahdon 2013 (2013a). Kansalaisaloite Tasa-arvoisen Avioliittolain Puolesta (Citizen's Initiative for Equal Marriage Law). Retrieved from: http://www.tahdon2013.fi/ (accessed on 03.07.2020).

Tahdon 2013. (2013b). Citizen's initiative. Retrieved from: http://www.tahdon2013.fi/inenglish/why-a-citizens-initiative/ (accessed on 03.07.2020)

Tamanaha, B. Z. (2006). A Socio-Legal Methodology for the Internal/External Distinction: Jurisprudential Implications. Fordham Law Review, 75(3), 1255-1274.

Tasioulas, J. (2015). On the Foundation of Human Rights. In: Cruft, R., Liao, M. and Renzo, M. (eds.), Philosophical Foundation of Human Right (2015, pp. 45-70), New York: Oxford University Press. DOI:10.1093/acprof:oso/9780199688623.003.0002.

Tesón, F. R. (1985). International Human Rights and Cultural Relativism. In: Hayden, P. (ed.), The Philosophy of Human Rights (2001, pp. 379-396). St. Paul: Paragon. ISBN-13: 978-1557787903.

The Independent. (2018). Denmark becomes latest European country to ban burqas and niqabs. Retrieved from:

https://www.independent.co.uk/news/world/europe/denmark-burqa-baneurope-muslim-women-face-veil-niqab-islam-a8377586.html (accessed on 03.07.2020).

Tomuschat, C. (2003). Human Rights: Between Idealism and Realism. New York: Oxford University Press. ISBN: 9780199683734.

Uusitalo, J. (2018a). From Legislative Shortcomings towards Better Protection of Human Rights: Analysis of Legislation on the Emergency Medical Service in 
Finland and Estonia. European Journal of Health Law, 25(4), 389-406.

DOI: https://doi.org/10.1163/15718093-12540387.

Uusitalo, J. (2018b). Protecting Economic Interests or the Right to Life? Perception of the European Court of Justice on Emergency Medical Services. Baltic Journal of European Studies, 8(1), 197-209. DOI: https://doi.org/10.1515/bjes-2018-0011.

Uusitalo, J. (2018c). Responsibility to Protect and Human Security: Doctrines Destroying or Strengthening the Sovereignty?. International and Comparative Law Review, 18(1), 93-107. DOI: 10.2478/iclr-2018-0027.

Van der Hemel, E. (2008). Included but not Belonging: Badiou and Ranciére on Human Rights. Krisis/Journal of Contemporary Philosophy, 2008(3), 16-30.

Weithman, P. (2009). John Rawls and the Task of Political Philosophy. The Review of Politics, 71(1), 113-125.

Wolff, J. (2015). The Content of the Right to Health. In: Cruft, R., Liao, M. and Renzo, M. (eds.), Philosophical Foundation of Human Rights (2015, pp. 491-501). New York: Oxford University Press.

DOI:10.1093/acprof:oso/9780199688623.003.0028. 
